\title{
ASSESSMENT OF ENTREPRENEURIAL INTENTIONS OF UNIVERSITY STUDENTS ACCORDING TO DEMOGRAPHIC FACTORS
}

\author{
Ahmet MASLAKÇI' ${ }^{1}$ Lütfi SÜRÜCÜ
}

\begin{abstract}
Entrepreneurship is considered to be one of the best resolution to unemployment and economic development problems. In order to enhance entrepreneurship in an economy; policymakers should focus on promoting university students' entrepreneurial intentions. In this context, the study examines the differences in entrepreneurship intentions of university students according to demographic variables. The data were achieved from 574 students studying at universities in the Turkish Republic of Northern Cyprus. The data were analyzed with the help of the SPSS-23 program. The research also shows the effect of gender and university education on the entrepreneurial intentions. In the study, these findings are discussed and recommendations are made for practitioners and policy makers of university education.
\end{abstract}

Keywords: Demographic Factors, Entrepreneurial Intentions, University Students JEL Classification: O31, N30

\section{ÜNIVERSiTE ÖĞRENCILERININ GiRişiMCiLiK NIYETLERIN DEMOGRAFIK ÖZELLIKLERINE GÖRE INCELENMESI}

Öz

Girişimciliğin işsizlik ve ekonomik kalkınma sorunlarına en büyük çözüm olduğuna inanılmaktadır. Bir ekonomide girişimciliği teşvik etmek için politika yapıcılarının, üniversite öğrencilerinin girişimcilik niyetlerini teşvik etmeye odaklanmalıdır. Bu bağlamda, araştırma üniversite öğrencilerinin girişimcilik niyetlerinin demografik değişkenlere göre farklııklarını incelemektedir. Veriler Kuzey Kıbrıs Türk Cumhuriyetin'de ki üniversitelerde eğitim gören 574 öğrenciden elde edilmiştir. Elde edilen veriler SPSS-23 programı yardımıyla analiz edilmiştir. Sonuçlar, üniversite öğrencilerinde girişimcilik niyetlerinin demografik özelliklerine göre (yaş, iş tecrübesi, aile gelir durumu ve eğitim gördüğü üniversite) farklılaştığını göstermektedir. Araştırma ayrıca cinsiyetin ve üniversite eğitiminin de, girişimcilik niyeti üzerinde ki etkisini göstermektedir. Araştırmada elde edilen bu bulgular, tartışılmakta ve üniversite eğitiminin pratisyenleri ve politika yapıcıları için önerilerde bulunulmaktadır.

Anahtar Kelimeler: Demografik Faktör, Girişimcilik Niyeti, Üniversite Öğrencileri JEL Sınıflandırması: O31, N3O

\footnotetext{
${ }^{1}$ Asst. Prof., Cyprus Science University, Faculty of Economics and Administrative Sciences, Department of Business, ahmetmaslakci@csu.edu.tr, ORCID:0000-0001-6820-4673

2 Phd, European Leadership University, Faculty of Economics and Administrative Sciences, Department of Business, lutfi.surucu@elu.edu.tr, ORCID: 0000-0002-6286-4184
} 


\section{Introduction}

Universities promote economic activities as a driving force of regional economies (Kadiyono et al., 2019:54), contributing to knowledge and technological development (Fernández-Pérez et al., 2019:2). Taking into account these positive impact of entrepreneurship, many emerging countries consider entrepreneurship as the main solution to problems such deprive from economic recovery, increased unemployment rates, an extreme number of university graduates, and inadequacy in both the private and public industries (Karimi et al., 2014:695). Studies show that improving entrepreneurship levels of university students will help alleviate the employment pressure faced by countries (Atilla and Kunday, 2016:69; Li and Wu, 2008:752). The creation of a new job takes place in progress of time, and the initial step in this period is entrepreneurial intentions (De Clercq, Honig and Martin 2013:23). Entrepreneurial intention shows a person's interest in developing an enterprise and choosing another job path different from the common tendencies (Schjoedt and Shaver, 2007:734). Based on the assumption that intentions are the best predictors of behavior, Planned Behavior Theory (Ajzen and Sheikh, 2013:155) is very important in the evaluation of entrepreneurial behavior (De Clercq, Honig and Martin 2013:5). In "The Planned Behavior Theory", demographic agents function as background factors that can jointly influence intention formation through their effects on one or more of the antecedent of intention (Fishbein and Ajzen 2010:282). Understanding the agants that affect the entrepreneurial intentions and behaviors of university students is important in developing effective strategies to promote these factors (Karimi et al., 2014:695). In other words, defining an appropriate theoretical framework and understanding the antecedents of university students' entrepreneurship intentions can help instructors and policymakers develop entrepreneurship that started in universities.

It has been suggested that demographic factors such as age and gender have an impact on entrepreneurial intention (Kristiansen and Indarti, 2004:58). Generally, Women have lower entrepreneurship intentions than men (Guerrero et al., 2016:95; Kelley et al., 2016:19). Research findings show that both male and female students want to set up their private enterprise, but boys are feeling more prepared now (Samuel, Ernest and Awuah, 2013:40). According to Ahl (2006:15), examining the demographic variations in entrepreneurship in developing countries is seen as a encouraging aspects for new investigations. In the literature; demographic variables, gender, family experience, and education level in the business world are considered to be the most important determining agents affecting the entrepreneurship of university students (Fragoso et al., 2020:19). In some studies; family income status, ethnicity, and citizenship have no effect on university students' entrepreneurial intentions (Aykol and Gürbüz, 2008:53; Wang and Wong, 2004:170; Zain et al., 2010:41). The way students think and behave affect their decision to become entrepreneurs (Samuel, Ernest and Awuah, 2013:40).

There is still a need for studies that analyze and compare the effects of demographic differences on the entrepreneurship period in universities (Turhan, 2020:161; Entrialgo and Iglesias, 2016:1213; Miranda et al., 2017:2). In addition, in the literature, the research gap regarding entrepreneurship studies of developing countries with a transition economy such as the Turkish Republic of Northern Cyprus is mentioned (Duong et al., 2020:600). In the study of Israr and Saleem (2018:7-11), It is stated that demographic differences are among the most important antecedent that determines the entrepreneurial intentions of university students. Researchers suggest that the studies should have been implemented in various countries and samples. In this respect, the main purpose of this study is to contribute to this gap in the literature. This study also provides policymakers and educational administrators with useful practical suggestions for improving university students' entrepreneurial intentions. Thus, it will be possible to design educational programs and constructive practices that will improve entrepreneurship intentions through entrepreneurial learning, according to the gender, age, and educational status of university students. 


\section{Theoretical Framework and Hypothesis Development}

Moriano et al. (2012:3) described entrepreneurial intention as "a conscious mood that precedes entrepreneurial behavior such as starting a new business and being an entrepreneur". Entrepreneurship intention expresses the intention to execute entrepreneurial behavior (Duong et al., 2020:601). Entrepreneurship researchers have adopted "social cognition" models in order to identify the main cognitive predictive factors of entrepreneurial intention and behavior that affects this behavior (Kolvereid, 1996:24). In this context, Ajzen's (1988:158, 1991:183), "Theory of Planned Behavior" states that intention is the most important predictive factor of behavior. The Planned Behavior Theory is designed to predict and explain human behavior in certain contexts. This model assumes that broad attitudes and personality traits have only an indirect effect on certain behaviors by affecting factors closer to the action in question (Ajzen, 1991:185). According to The Planned Theory of Behavior, 'general' attitudes, values, and beliefs of people are independent of their actions. Therefore, concepts that are closer to that behavior are needed to adequately explain a particular behavior, for example, the decision to become an entrepreneur (Ajzen, 1991:185).

According to Ajzen (1991:190), intentions are determined by attitudes towards behavior, subjective norms, and perceived behavior control. Attitude towards behavior means to what extent the individual has a positive or negative evaluation of the behavior in question. Subjective norm means perceived social pressure to perform or not perform the behavior. The third antecedent, perceived behavioral control, is related to the control beliefs of the individual towards the behavior. Demographic factors are a basic dimension of the social-cultural environment and are among the important determinants of entrepreneurship intent (Karimi et al., 2014:702). Demographic factors that differentiate entrepreneurial activities are age, gender, education, and job experience (Ismail et al., 2009:56). Many studies support the argument that demographic factors such as age and gender, education, and previous job experience have an impact on entrepreneurial participation (Kristiansen and Indarti, 2004:69). Studies in the literature show that age has a negative relationship with entrepreneurial intention (Fung et al., 2001:355; Lévesque and Minniti, 2006:180). In the study of Brieger et al. (2020:16), empirical findings were obtained that provide strong support between the age of individuals and their entrepreneurial intentions. Although age is not commonly considered as an important determinant of business ventures, Reynolds et al. (2000) found that individuals aged between "25-44" are the most active group in entrepreneurship efforts in Western countries. Entrepreneurship age is admitted to be 30-35 in studies conducted in the United States (Ottih, 2011) and in other countries (Agbim et al., 2013:41). The findings of a study in India show that successful entrepreneurs are relatively young (Sinha, 1996:10). In studies, there is strong empirical support for an inverted U-shaped relationship between individuals' age and entrepreneurial motivations, intentions, and behaviors and It suggests that middle-aged individuals are typically more likely to show interest or not. Despite the increasing number of women entrepreneurs (Thébaud, 2010:291) entrepreneurship is still associated with masculine traits (Gupta et al., 2009:412) and female entrepreneurship remains significantly low (Langowitz and Minniti, 2007:355). In a study on university students in China; It is stated that male students are more likely to be entrepreneurs than female students (Plant and Ren, 2010:192). In the study conducted in Italy, entrepreneurship intentions of female students were determined to be lower than male students (Israr and Saleem, 2018:3). Kolvereid (1996:24) stated that individuals with previous entrepreneurial experience have significantly higher entrepreneurial intentions than those without such experience.

Based on the studies and theoretical discussions that mentioned above, it is evaluated that gender, age, education background, and job experiences can be effective on entrepreneurial intention. Stated theory and the above model, the following hypotheses were developed for empirical analysis in this study:

Hypothesis 1: Entrepreneurship intention of university students differs according to gender. 
Hypothesis 2: The entrepreneurship intention of university students differs according to age.

Hypothesis 3: The entrepreneurship intention of university students differs according to the family income

Hypothesis 4: The entrepreneurship intention of university students differs according to their job experience.

Hypothesis 5: The entrepreneurship intention of university students differs according to the universities in which they study

\section{Methodology}

Whether there are differences between entrepreneurship intentions according to the demographic factors of university students were examined by quantitative methods. Qualitative methods are researches based on observations and interviews. In qualitative methods, students can respond in line with the expectations of the researchers, or the researchers may be biased in their observations. In terms of quantitative methods, while these biases decrease, they provide explanatory and descriptive benefits for large-scale studies. For this reason, the determination of the perceptions of students towards entrepreneurship intention was investigated with quantitative methods and the survey method was preferred as a data collection tool.

\subsection{The Population and Sample}

The research was conducted on the students of five universities that continue their education in different destinations (Kyrenia, Nicosia, Famagusta) in the Turkish Republic of Northern Cyprus. First of all, the university deans were interviewed and the necessary permissions were obtained for the study. A survey was conducted on the basis of volunteering for university students, who were selected by the researchers with the convenience sampling method. In the survey study, questionnaire data were obtained from 589 students. 15 questionnaire data, which were evaluated as incomplete and incorrectly filled in by the researchers, were excluded from the scope of the research. The research was completed on valid 574 survey data.

269 of the participants are female and 305 are male. 180 of the participants are aged 20 and under, 272 of them are between the ages of 21-22, 72 of them are between the ages of 23-24, and 50 of them are over the age of 24 . The family income of 224 students (mother and father total income) is between 5000 10001 and above. While 165 of the students have job experience, 409 students do not have any job experience. While 125 students continue their education at Eastern Mediterranean University, 90 students continue their education at Girne American University, 111 students at Middle East Technical University, 97 students at Cyprus International University, and 151 students at Near East University.

\subsection{Measures}

Demographic Structure: It consists of five questions to determine the demographic factors of university students.

Entrepreneurship Intention: The related literature was examined to measure the entrepreneurship intention of university students and a scale consisting of six items developed by Liñán and Chen (2009) was used. The scale is a 6-point Likert type, ranging from completely disagree (1) to completely agree (6). Sample questions of the scale are as follows: "As an entrepreneur, I'm ready to do anything.", "I will make every effort to start and maintain my own business", "I seriously think of starting my own business" and "I am determined to start my own business in the future". Cronbach's alpha coefficient of the scale was measured as 0.910 in the study. 


\section{Findings}

In the study, after the numerical and percentage distribution of demographic features, analyzes were made in terms of the overall structure and part reliability. Factor analysis was used in order to test the construct validity of the entrepreneurship intention scale which was launched by Liñán and Chen (2009). Factor analysis is a multivariate analysis tool used to understand the relationship structure that underpins the data matrix. In the factor analysis, the Kaiser-Meyer-Olkin (KMO) sample adequacy value of 0.874 and $p<0.001$ indicates that the sample size is within the acceptable limits for factor analysis. In the primary component analysis applied to the data, the varimax factor return option was preferred and the data larger than Eigenvalue 1 was provided to be a factor. Factor analysis results show that the values reached for the single factor structure are statistically acceptable and suitable for other analyzes.

In the analyzes made for the reliability of the scale; Cronbach alpha internal consistency coefficient $(\alpha)$ was 0.910 , composite reliability $(\mathrm{Cr})$ was 0.931 , and average explained variance value (AVE) was 0.693. Composite reliability and Cronbach's alpha values greater than 0.7 and AVE value greater than 0.5 indicate that the scale is reliable for research (Hair, Black, Babin, Anderson and Tatham, 1998; Sürücü and Maslakçı, 2020:2701).

In Compare analyzes; Parametric tests are used when the data are normally distributed, and nonparametric analysis techniques are used if the data is not normally distributed. Within the framework of the analyzes made for determining the normal distribution, it was determined that the data had a normal distribution (Zskewness $=-0,427$, Z $Z_{\text {kurtosis }}=-0,616$ ) (Tabachnick, Fidell and UIIman, 2007:68) For this reason, parametric tests were applied in the study. According to the demographic factors of university students, t-test and one-way Anova tests were applied from parametric tests to determine whether entrepreneurship intention differs. In the analyzes made by considering the gender, age, family income status, job experience, and the university in which students are educated, it is seen that entrepreneurship intention differs according to certain situations.

Table 1. The T-Test Results Made for Comparing Entrepreneurship Intentions of University Students According to Their Gender

\begin{tabular}{cccccccr}
\hline & Gender & $\mathrm{N}$ & Mean & SD & $\mathrm{t}$ & $\mathrm{p}$ & Result \\
\hline $\begin{array}{c}\text { Entrepreneurship In- } \\
\text { tention }\end{array}$ & Female & 269 & 4.128 & 1.254 & & & \\
\hline
\end{tabular}

$* * p<0,05$ (a: Female, $b:$ Male)

The results of the t-test analysis was used to specify whether university students' entrepreneurship intention differs according to gender show that variances are homogeneous and there is no difference between entrepreneurship intention levels by gender $(t=-1.247, p>.05)$. In light of this finding, hypothesis 1 was rejected.

Table 2. The One-Way Anova Analysis Results for Comparison of University Students' Entrepreneurial Intentions According to Age Groups

\begin{tabular}{cccccccc}
\hline & Age group & $\mathrm{N}$ & Mean & SD & $\mathrm{F}$ & $\mathrm{p}$ & Results \\
\hline \multirow{3}{*}{$\begin{array}{c}\text { Entrepreneurship } \\
\text { Intention }\end{array}$} & $21-22$ & 272 & 4.173 & 1.215 & & & $\mathrm{~d}-\mathrm{a}$ \\
& $23-24$ & 72 & 4.468 & 0.979 & & & \\
& $>24$ & 50 & 4.593 & 1.046 & & & \\
\hline
\end{tabular}

${ }^{* *} p<0,05$ ( $a: 20$ years and under, $b: 21-22$ years, $c: 23-24$ years, $d:$ over 24 years) 
One-Way Anova test was applied to determine the differences between entrepreneurship intentions of university students according to age groups. The results are presented in Table 2

One-Way Anova analysis used to determine the variations between entrepreneurship intentions of university students according to age groups showed that variances are not homogeneous. For this reason, the Games-Howell test, which is one of the Post Hoc tests, was applied. Findings according to analysis results show that the entrepreneurship intention of students in the 21-22 and 23-24 age group is higher than the university students aged 20 and under. Based on this finding; It can be said that the entrepreneurship intention of higher age groups is higher than the students in the age group of 20 and under. In line with this finding, hypothesis 2 was accepted.

One-Way Anova analysis was used to specify the differences between entrepreneurship intentions of university students according to their families' income (mother and father total income). The results are presented in Table 3.

Table 3. One-Way Anova Analysis Results for Comparison of University Students' Entrepreneurial Intentions According to Family Income Status

\begin{tabular}{|c|c|c|c|c|c|c|c|}
\hline & Family Income & $\mathrm{N}$ & Mean & SD & $\mathrm{F}$ & $\mathrm{p}$ & Results \\
\hline \multirow{3}{*}{$\begin{array}{l}\text { Entrepreneurship } \\
\text { Intention }\end{array}$} & $\leq 5000$ & 224 & 4.151 & 1.281 & .975 & .378 & $c-a$ \\
\hline & $5001-10000$ & 320 & 4.201 & 1.202 & & & \\
\hline & $>10001$ & 30 & 4.486 & 1.186 & & & \\
\hline
\end{tabular}

One-Way Anova analysis on comparing entrepreneurship intention of university students according to family income status showed that variances are homogeneous. For this reason, the Tukey test, which is one of the Post Hoc tests, was applied. In line with the findings obtained in the light of the results of the analysis, the entrepreneurship intention of university students whose family income is $10001 \mathrm{TL}$ and above is higher than the university students whose family income is 5000TL and below. In line with this finding, hypothesis 3 was accepted.

T-test was used to determine the differences between university students' entrepreneurial intentions and job experience. The results are presented in Table 4.

Table 4. The T-Test Results Made for Comparing Entrepreneurship Intentions of University Students According to Their Job Experience

\begin{tabular}{lccccccc}
\hline & Job Experience & $\mathrm{N}$ & Mean & $\mathrm{SD}$ & $\mathrm{t}$ & $\mathrm{p}$ & Results \\
\hline $\begin{array}{c}\text { Entrepreneurship } \\
\text { Intention }\end{array}$ & Yes & 165 & 4.446 & 1.113 & & & \\
$* * * p<0,001(a:$ Yes, $b:$ No) & No & 409 & 4.095 & 1.267 & -3.269 & $.001^{* * *}$ & $\mathrm{a}-\mathrm{b}$ \\
& & & & & & &
\end{tabular}

The results of the t-test analysis were occured to determine whether there is a difference in entrepreneurship intentions according to the job experience of the university students showed that the variances are homogeneous and that the entrepreneurship intention of the university students with job experience is higher than those without job experience $(t=-3.269, p<.001)$. Based on the findings, hypothesis 4 was accepted.

One Way Anova test was applied to determine the differences between entrepreneurship intentions according to the universities in which students study. The results are showed in Table 5. 
Table 5. One-Way Anova Analysis Results for Comparison of University Students' Entrepreneurial Intentions According to the universities in which students study

\begin{tabular}{cccccccc}
\hline & University & $\mathrm{N}$ & Mean & SD & $\mathrm{F}$ & $\mathrm{p}$ & Results \\
\hline & EMU & 125 & 4.166 & 1.208 & 4.852 & $.001^{* * *}$ & $\mathrm{a}-\mathrm{e}$ \\
$\begin{array}{c}\text { Entrepreneurship } \\
\text { Intention }\end{array}$ & GAU & 90 & 4.313 & 1.137 & & $\mathrm{~b}-\mathrm{e}$ & $\mathrm{c}-\mathrm{e}$ \\
& METU & 111 & 3.782 & 1.199 & & & \\
& CIU & 97 & 4.468 & 1.243 & & & \\
& NEA & 151 & 4.282 & 4.282 & & & \\
\hline
\end{tabular}

${ }^{* * *} p<0,001$ (a: Eastern Mediterranean University (EMU), b: Girne American University (GAU), c: Middle East Technical University (METU), d: International Cyprus University (CIU), e: Near East University (NEA))

In the study, the One Way Anova analysis were occured in order to specified whether entrepreneurship intentions according to the universities in which university students study showed that the variances are homogeneous differ or not. For this reason, the Tukey test, which is one of the Post Hoc tests, was applied. In line with the findings according to the analysis results; It has been determined that the entrepreneurship intention of students studying at Eastern Mediterranean University, Girne American University, and Middle East Technical University is higher than the students studying at Near East University. In line with this finding, hypothesis 5 was accepted.

\section{Conclusion}

The aim of this study is to determine whether entrepreneurship intentions of university students differ according to demographic factors. The Planned behavior theory provides a theoretical framework to examine the demographic factors that affect the individual's attitude, perceived social pressure, and potential to control his/her entrepreneurial perception (Ahmed, Klobas and Ramayah, 2019:2). Our results demonstrated that differences in personality traits can affect the entrepreneurial intention formatio and moreover possess traits to influence attitude and perceived control antecedents. In the literature; demographic and personal factors are considered to be the most important determining factors for entrepreneurship among university students (Fragoso et al., 2020:21). The results of the study confirm many previous findings regarding the effect of demographic differences of students on entrepreneurial intentions in the literature. Our results show that " the university in which students study, age, family income status and job experience" cause differentiation in university students' entrepreneurial intentions. Unlike many studies in the literature (Plant and Ren, 2010:201; Miranda et al., 2017:4), the university students' entrepreneurial intention does not differ by gender. This result of the study overlaps with studies showing that there are similarities between the genders towards entrepreneurship intention than those that indicate that there are differences between the genders (Bae et al., 2014:223; Goel et al., 2015:171; Kristiansen and Indarti, 2004:71). It is seen that entrepreneurship intentions differ according to the universities where they are educated. A meta-analysis study on entrepreneurship intention and education shows that education has a positive contibution on the "entrepreneurial mindset" development (van der Sluijs et al., 2008:800). In this context, many economical theories based on career selection. Douglas and Shepherd (2002:86) stated that young people have a higher possibility of making a long-run profit from their entrepreneurship.

Rauch and Hulsink (2015:190) emphasize that education about is the antecedent of entrepreneurship intention. Accordingly, entrepreneurship education, which makes a significant difference in students' entrepreneurship intentions, also increases the knowledge and skills of individuals (Israr and Saleem, 2018:5). Therefore, the entrepreneurship intentions of stu- 
dents differ according to the education provided by universities. Empirical studies suggest that deprive from capital is seen as the main obstacle for most young people who have own business and that capital can be provided in the form of gifts, family support, friendly or financial loans. Young people who run their own business often receive economical support from their families as well.

If the children family have business background, it is more likely to often get their children started to participate in entrepreneurial activities and expect them to liekly to start their own managemenet in the future (Van Auken et al., 2006:330). Family and environmental support are crucial factors in the development of students' entrepreneurial intentions (Eryılmaz and Dirik, 2016:7). Under financial security conditions, the basic needs of young entrepreneurs are usually met by families. In this context, the income levels of students' families affect entrepreneurship intentions. These results are similar to the results of the study.

In the study of Iversen et al. (2016:453), they emphasize that entrepreneurship education and paid work experience of university students are strong complements of entrepreneurship intention. The job experience of university students during their school life improves their skills. Unless the skills acquired at universities match the correct practical experience, university students cannot fully develop their entrepreneurial intentions (Iversen et al., 2016:455). In the study, the result of past job experiences that are factors affecting entrepreneurship intention of students coincides with the previous literature results.

The entrepreneur is the person who started his/her own company (Poutziouris, 2003:186). Therefore, entrepreneurs are very important for national and regional economic development (Sadler-Smith, Hampson, Chaston and Badger, 2003:49). In this sense, entrepreneurship can be counted as a strategic phonemenon and needs to be investigated at the macro level. Governments should include entrepreneurship issues in their development plans and support them nationwide. It is considered that it will be beneficial to include entrepreneurship in the education policies of the governments. In this context, factors that affect entrepreneurship intentions of university students should be examined extensively. Thus, necessary regulations can be made in the higher educatory system to develop the entrepreneurial intention of the youth in the country.

This study finds out important information for those who design, implement, and review educatory programs that aim to strengthen students' entrepreneurial intentions beyond special education for entrepreneurship. This study has implications for researchers, universities and policymakers. If the factors affecting the entrepreneurship intention of university students are understood, universities, government, and other interested parties can develop programs that turn these "potential entrepreneurs" in new entrepreneurs. Today, especially the business school curriculum tends to focus strongly on bureaucratic-related technical management skills rather than entrepreneurial activities. Our findings emphasize the determination of a policy focused on demographic differences in entrepreneurship intentions of university students. According to McManus (2001:72) and Ahl (2006:18), determining demographical variations in entrepreneurship in developing countries is considered as a promising process. In this context, it is important to examine the demographic differences that determine the entrepreneurship intention behaviour of university students.

The results of this study have limitations that elicit possibilities for future research. First; the fact that the cultural differences of university students are not included in the study is considered as one of the most important limitations. It is anticipated that culture will be an important factor especially in family support and gender differences. Secondly; in the study, departments of university students were not included in the evaluation. Consequently, future studies may include a research design that includes comparative qualitative and quantitative evaluations that examine the relationships and interactions described in this study in different cultures and conditions. 


\section{References}

Agbim, K. C., Oriarewo, G. O. and Owocho, M. (2013). Factors Influencing Entrepreneurial Intentions Among Graduates of Nigerian Tertiary Institutions. International Journal of Business and Management Invention, 2(4), 36-44.

Ahl, H. J. (2006). Why Research on Women Entrepreneurs Needs New Directions. Entrepreneurship Theory and Practice, 30(5), 595-621.

Ahmed, T., Klobas, J. E. and Ramayah, T. (2019). Personality Traits, Demographic Factors and Entrepreneurial Intentions: Improved Understanding from a Moderated Mediation Study. Entrepreneurship Research Journal, 20170062.

Ajzen, I. (1988). Attitudes, Personality, and Behaviour, Open University Press, Buckingham.

Ajzen, I. (1991). The Theory of Planned Behaviour. Organizational Behavior and Human Decision Processes, 50(2), 179-211.

Ajzen, I. and Sheikh, S. (2013). Action Versus Inaction: Anticipated Affect in the Theory of Planned Behavior. Journal of Applied Social Psychology, 43(1). 155-162.

Atilla Oner, M. and Kunday, O. (2016). A study on Schumpeterian and Kirznerian Entrepreneurship in Turkey: 2006-2013. Technology Forecast Social Change, 102, 62-71.

Aykol, S. and Gurbuz, G. (2008). Entrepreneurial Intentions of Young Educated Public in Turkey. Journal of Global Strategic Management, 4, 47-55.

Bae, T. J., Qian, S., Miao, C. and Fiet, J. O. (2014). The Relationship between Entrepreneurship Education and Entrepreneurial Intentions: A Meta-Analytic Review. Entrepreneurship Theory and Practice. 38, 217-254.

Brieger, S. A., Bäro, A., Criaco, G. and Terjesen, S. A. (2020). Entrepreneurs' Age, Institutions, And Social Value Creation Goals: A Multi-Country Study. Small Business Economics, 1-29.

De Clercq, D., Honig, B. and Martin, B. (2013). The Roles of Learning Orientation and Passion for Work in the Formation of Entrepreneurial Intention. International Small Business Journal 316(6), 652-676.

Douglas, E. J. and Shepherd, D. A. (2002). Self-employment as a Career Choice: Attitudes, Entrepreneurial Intentions, and Utility Maximization. Entrepreneurship Theory and Practice, 26(3), 81-90.

Duong, C., Nguyen, H., Ngo, T., Nguyen, V. and Nguyen, T. (2020). The Impact of Individual and Environmental Characteristics on Students' Entrepreneurial Intention. Management Science Letters, 10(3), 599-608.

Entrialgo, M. and Iglesias, V. (2016). The Moderating Role of Entrepreneurship Education on the Antecedents of Entrepreneurial Intention, International Entrepreneurship and Management Journal, 12(4), 1209-1232.

Eryılmaz, D. Ö. İ. and Dirik, A. G. D. (2016). Girişimcilik Niyeti Üzerine Nitel Bir Araştırma: Manisa Celal Bayar Üniversitesi Örneği. Manisa Celal Bayar Üniversitesi Örneği. Gençlerle 360 Derece 3. Uluslararası Öğrenci Kongresi, 1-10.

Fernández-Pérez, V., Montes-Merino, A., Rodríguez-Ariza, L. and Galicia, P. E. A. (2019). Emotional Competencies and Cognitive Antecedents in Shaping Student's Entrepreneurial Intention: The Moderating Role of Entrepreneurship Education. International Entrepreneurship and Management Journal, 15(1), 281-305.

Fishbein, M. and Ajzen, I. (2010). Predicting and Changing Behavior the Reasoned Action Approach. New York: Taylor \& Francis 
Fragoso, R., Rocha-Junior, W. and Xavier, A. (2020). Determinant Factors of Entrepreneurial Intention among University Students in Brazil and Portugal, Journal of Small Business \& Entrepreneurship, 32(1), 1-25.

Fung, H. H., Lai, P. and Ng, R. (2001). Age Differences in Social Preferences among Taiwanese and Mainland Chinese: The Role of Perceived Time, Psychology and Aging, 16(2), 351-356.

Goel, R. K., Göktepe-Hultén, D. and Ram, R. (2015). Academics' Entrepreneurship Propensities and Gender Differences, The Journal of Technology Transfer, 40(1), 161-177.

Guerrero, M., Urbano, D., Ramos, A., Ruiz-Navarro, J., Neira, I. and Fernández-Laviada, A. (2016). Perfil Emprendedor del Estudiante Universitario. Retrieved from http://www.cise.es/gem/Informe- Observatorio-Emprendimiento-Universitario.pdf

Gupta, V. K., Turban, D., Wasti, S. A. and Sikdar, A. (2009). The Role of Gender Stereotypes in Perceptions of Entrepreneurs and Intentions to Become an Entrepreneur", Entrepreneurship Theory and Practice, 33(2), 397-417.

Hair, J. F., Black, W. C., Babin, B. J., Anderson, R. E. and Tatham, R. L. (1998). Multivariate Data Analysis (Vol. 5, No. 3, pp. 207-219). Upper Saddle River, NJ: Prentice Hall.

Ismail M., Khalid S. A., Othman M., Jusoff H. K., Rahman N. A., Kassim K. M. and Zain R.S. (2009). Entrepreneurial Intentions among Malaysian Students, International Journal of Business and Management, 4(10), 54-60.

Israr, M. and Saleem, M. (2018). Entrepreneurial Intentions among University Students in Italy. Journal of Global Entrepreneurship Research, 8(1), 20.

Iversen, J., Malchow-Møller, N. and Sørensen, A. (2016). Success in Entrepreneurship: A Complementarity between Schooling and Wage-Work Experience. Small Business Economics, 47(2), 437-460.

Kadiyono, A., Sulistiobudi, R. and Zulhijah, A. (2019). Why College Students Have Big Motivation to Start Their Own Business, but Not Continuing The Business After Graduate?. In 5th Bandung Creative Movement International Conference on Creative Industries 2018 (5th BCM 2018). Atlantis Press.

Karimi, S., Biemans, H. J., Lans, T., Chizari, M. and Mulder, M. (2014). Effects of Role Models and Gender on Students' Entrepreneurial Intentions. European Journal of Training and Development. 38 (8), 694-727.

Kelley, D. J., Baumer, B. S., Brush, C., Greene, P. G., Mahdavi, M., Majbouri Marcia Cole, M., et al. (2016).Women's entrepreneurship 2016/2017 report. Global Entrepreneurship Monitor, 1-91.

Kolvereid, L. (1996). Organizational Employment Versus Self-Employment: Reasons for Career Choice Intentions, Entrepreneurial Theory and Practice, 20(3), 23-31.

Kristiansen, S. and Indarti, N., (2004), Entrepreneurial Intentions among Indonesian and Norwegian Students, Journal of Enterprising Culture, 12(1), 55- 78.

Langowitz, N. and Minniti, M. (2007). The Entrepreneurial Propensity of Women, Entrepreneurship, Theory and Practice, 31(3), 341-364.

Lévesque, M. and Minniti, M. (2006). The Effect of Aging on Entrepreneurial Behaviour. Journal of Business Venturing, 21(2), 177-194.

Li, J., Wu, S. and Wu, L. (2008). The Impact Oof Higher Education on Entrepreneurial Intentions of University Students in China. Journal of Small Business and Enterprise Development, 15(4), 752-774. 
Liñán, F. and Chen, Y. W. (2009). Development and Cross-Cultural Application of a Specific Instrument to Measure Entrepreneurial Intentions. Entrepreneurship Theory and Practice, 33(3), 593-617.

McManus, P. A. (2001). Women's Participation in Self-Employment in Western Industrialized Nations, International Journal of Sociology, 31(2), 70-97.

Miranda, F. Javier, A. C, Sergio R. and Jesús P. M. (2017).Academic Entrepreneurial Intention: The Role of Gender. International Journal of Gender and Entrepreneurship, 9(11), 66-86.

Moriano, J. A., Gorgievski, M., Laguna, M., Stephan, U. and Zarafshani, K. (2012). A Cross-Cultural Approach to Understanding Entrepreneurial Intention. Journal of Career Development, 39(2), 162-185.

Ottih, L. O. (2014). Entrepreneurship: Personality, Process and Enterprise. Port Harcourt: Pearl.

Plant, R. and Ren, J. (2010). Comparative Study of Motivation and Entrepreneurial Intentionality: Chinese and American Perspectives, Journal of Development Entrepreneurship, 15(2), 187-204.

Poutziouris, P. (2003), The Strategic Orientation of Owner/Managers of Small Ventures, International Journal of Entrepreneurial Behaviour and Research, 9(5), 185-214.

Rauch, A. and Hulsink, W. (2015). Putting Entrepreneurship Education where the Intention to Act Lies: An Investigation into the Impact of Entrepreneurship Education on Entrepreneurial Behavior. The Academy of Management Learning and Education, 14(2), 187-204.

Reynolds, P. D., Hay, M., Bygrave, W. D., Camp, S. M. and Aution, E. (2000) Global Entrepreneurship Monitor, 2000 Executive Report, A Research Report from Babson College, Kauffman Center for Entrepreneurial Leadership, and London Business School.

Sürücü, L. and Maslakçı, A. (2020). Validity and Reliability in Quantitative Research. Business \& Management Studies: An International Journal, 8(3), 2694-2726.

Sadler-Smith, E., Hampson, Y. Chaston, I. and Badger, B. (2003). Managerial Behavior, Entrepreneurial Style and Small Firm Performance, Journal of Small Business Management, 41(1), 47-67.

Samuel, Y. A., Ernest, K. and Awuah, J. B. (2013). An assessment of Entrepreneurship Intention Among Sunyani Polytechnic Marketing Students. International Review of Management and Marketing, 3(1), 37.

Sayli, H., Baytok, A. and Soybali, H. H. (2010). The Effects of Employees' Demographic Characteristics on the Perception of Organizational Culture: A Study in Service Enterprise. In 2nd International Symposium on Sustainable Development, 198-204.

Schjoedt, L. and Shaver, K. G. (2007). Deciding on an Entrepreneurial Career: A Test of the Pull and Push Hypotheses Using the Panel Study of Entrepreneurial Dynamics Data. Entrepreneurship Theory and Practice, 31(5), 733-752.

Sinha, T. N. (1996). Human Factors in Entrepreneurship Effectiveness, Journal of Entrepreneurship, 5(1), 23-39.

Tabachnick, B. G., Fidell, L. S. and Ullman, J. B. (2007). Using Multivariate Statistics (Vol. 5). Boston, MA: Pearson.

Thébaud, S. (2010). Gender and Entrepreneurship as a Career Choice, Social Psychology Quarterly, 73(3), 288-297. 
Turhan, N. S. (2020). Analysis on Entrepreneurial Intentions and Motivation and Learning Strategies of University Students. International Journal of Educational Research Review, 5(2), 159-164.

Van Auken, H., Stephens, P., Fry, F. and Silva, J. (2006). Role Model Influences on Entrepreneurial Intentions: A comparison between USA and Mexico", The International Entrepreneurship and Management Journal, 2(3), 325- 336.

Van der Sluijs, J., van Praag, M. and Vijverberg, W. (2008). Education and Entrepreneurship Selection: A Review of the Empirical Literature. Journal of Economic Surveys, 22(5), 795-841.

Wang, C. K. and Wong, P. (2004). Entrepreneurial Interest of University Students in Singapore. Technovation, 24, 163-172.

Zain, Z. M., Akram, A. M. and Ghani, E. K. (2010). Entrepreneurial Intention among Malaysian Business Students. Canadian Social Science, 6(3), 34-44. 